\title{
FORA DO TEMPO
}

http://dx.doi.org/10.11606/issn.2237-1184.v0i26p113-114

\author{
Jaco Guinsburg \\ Professor, escritor, editor, e grande amigo de Boris Schnaiderman
}

Outro dia, correndo os olhos por minha estante, detive-me, por acaso, com a coletânea de contos de Maksin Górki, traduzidos para o português. Era uma publicação da Philobiblion, do Rio de Janeiro, numa reedição da versão anterior de 1962 da Civilização Brasileira. O tradutor, pela reconhecida qualidade de sua contribuição nessa área, suscitou em mim a vontade de relê-los. E, ao fazê-lo, pareceu-me que o reencontro desses relatos com o eu-leitor gerou em minha imaginação não só o mundo pelo qual sempre fui atraído, como pelo encanto e a modulação de uma escrita. E isso por vários motivos.

O primeiro é que, fiel aos princípios que veio guiando o seu trabalho nesse domínio, o tradutor reviu a racolta gorkiana com o mesmo cuidado que dedicou a outras traduções suas, de autores russos, reimpressas nos últimos anos, como ocorreu especialmente com os relatos de Tchékhov, em 1985. E o resultado desse esforço foi dos mais compensadores para o leitor de língua portuguesa.

Mas, independentemente da maior confiabilidade da versão, na medida em que ela passou a ser produto de sucessivos cotejos rigorosos com o original, o que importa em realizações desse gênero, e é marcante no caso em exame, é a qualidade literária da transposição. É claro que o brilho é de Górki, cabe supor, mas, em português, não deixa de ser, e em larga medida, também a de seu veiculador nesta língua. Aliás, trata-se de uma característica que o distinguiu ao longo do tempo como tradutor de ficção. A sensibilidade e a garra de ficcionista afeito ao corpo a corpo com a palavra conferiram a seus textos, no pormenor designativo e na articulação configurativa, uma precisão vocabular e uma fluência de linguagem relevantes, colocando-se entre o que de melhor se fez em nosso meio, em matéria de tradução do russo, como os comentários críticos assinalaram reiteradas vezes.

$\mathrm{Na}$ verdade, efetuando um verdadeiro trabalho de recriação do escrever gorkiano, Boris Schnaiderman parecia possuir para cada sugestão 
ou referência textual do autor russo a expressão adequada e funcional em português, ou seja, a transcriação que, à vista e à impressão ledora, se ajustava como uma luva ao fluxo narrativo e às nomeações que o compõem. E isso sem incidir nos antigos espartilhos literários do "bom" estilo padronizado.

Mas antes, ao contrário, depurando do que ainda restava de suas imposições na primeira apresentação dos contos ou em vernáculo a linguagem de Górki flui, nessas condições, como se tivesse sido concebida e grafada em nosso idioma, sem que os estrangeirismos russos necessários, sem dúvida, para exprimir elementos específicos e, mais ainda para colorir com matrizes locais diferentes aspectos dos textos introduzam uma perturbação na leitura. Essa qualidade tornou-se tanto mais valiosa quanto as histórias gorkianas tão marcantes na sua caracterização da paisagem humana russa abordada pelo escritor não são menos expressivas com respeito à paisagem que as cerca. Um dos traços talvez mais peculiares do autor é o seu pincel de pintor da natureza. As suas tintas verbais são carregadas de tons subjetivantes que constituem mais uma expressão da sua marcada tendência romântica. Para acompanhá-lo nessa captação lírica dos ambientes é preciso contar com recursos linguístico e sensibilidade poética. E ambos não faltaram ao tradutor. Por outro lado, cabe assinalar a precisão de seu verbo nas caracterizações objetivas e materiais das ações e do quadro em que se movem as personagens de Górki.

Com isso, as referências psicológicas e sociais dessa humanidade que no seu desarraigamento, na sua vagabundagem, na sua orfandade material e, às vezes, espiritual, fica entre a miséria de suas vicissitudes de vida e a riqueza de suas potencialidades humanas e espirituais, o que se traduz, no plano ficcional, num jogo nem sempre bem rematado entre fortes retratos realistas e vagos anseios românticos.

A distância abolida do tempo do mundo gorkiano desfaz-se na realidade da vida e ela é também da morte, fatalidade que não deixou escapar, depois de escritas estas linhas, um homem que consagrou sua vida à palavra dos homens.

À memória de Boris Schnaiderman.

20 de maio de 2016 